\title{
Transportes, região e desenvolvimento econômico

\author{
a dinâmica da expansão da infra-estrutura viária \\ na província de Minas Gerais, 1840-1889*
}

\author{
Transportation, region \\ and economic development \\ the dynamics of roadway infrastructure expansion \\ in the province of Minas Gerais, 1840-1889
}

\author{
LIDIANY SILVA BARBOSA** \\ CEDEPLAR \\ Universidade Federal de Minas Gerais \\ Belo Horizonte (MG) \\ Brasil \\ MARCELO MAGALHÃES GODOY*** \\ CEDEPLAR \\ Universidade Federal de Minas Gerais \\ Belo Horizonte (MG) \\ Brasil
}

RESUMO O artigo contempla o quadro geral das obras realizadas na infra-estrutura de transportes tradicionais pelo Governo Provincial de Minas Gerais, entre 1840 e 1889. As fontes principais são os Processos de Construção de Estradas e Pontes, geradas no âmbito da Secretaria de Obras Públicas e que abarcam extensa e complexa documentação sobre todas

\footnotetext{
* $\quad$ Artigo recebido em: 08/08/2013. Aprovado em: 26/05/2014.

** Contato: lidiany@cedeplar.ufmg.br.

*** Contato: mmgodoy@cedeplar.ufmg.br.
} 
as fases das intervenções viárias realizadas na província. Os resultados fundamentais afirmam forte correlação entre o nível de desenvolvimento econômico das regiões mineiras e a incidência de obras públicas viárias, a revelar pronunciado desequilíbrio na distribuição dos recursos financeiros provinciais destinados a infra-estrutura de transportes de Minas Gerais.

Palavras-chave transportes, desenvolvimento econômico, província de Minas Gerais

ABSTRACT The article covers the general situation of works carried out in the traditional roadway infrastructure by the Provincial Government of Minas Gerais, between 1840 and 1889. The principal sources are Road and Bridge Construction Processes, generated within the scope of the Public Works Office, and which cover an extensive and complex documentation about all the phases of road interventions conducted in the province. The fundamental results show a strong correlation between the level of economic development of the regions in Minas Gerais and the occurrence of public road works, revealing a pronounced imbalance in the distribution of financial resources in the province allocated for transportation infrastructure in the province.

Keywords transportation, economic development, Minas Gerais province

\section{Introdução}

Este estudo apresenta perfil geral das intervenções na infra-estrutura de transportes tradicionais, ${ }^{1}$ realizadas pelo Governo Provincial de Minas Gerais, entre as décadas de 1840 e 1880. Com base em apreensão regionalizada do espaço, discute-se a distribuição das obras viárias, tendo por referência alguns parâmetros importantes para a implementação de políticas de transportes, como a configuração do território, as características demográficas e o processo de desenvolvimento econômico.

Compreender a dinâmica da construção e manutenção da infra-estrutura viária é aspecto fundamental para a história dos transportes de Minas Gerais no século XIX. Trata-se de verticalizar a análise para o período anterior à revolucionária² era ferroviária mineira, que na historiografia dos transportes,

1 Para a caracterização geral dos transportes tradicionais, ver: GOULART, José Alípio. Meios e instrumentos de transportes no interior do Brasil. Rio de Janeiro: MEC, Serviço de Documentação, Departamento de Imprensa Oficial, 1959. Para a caracterização dos transportes tradicionais de Minas Gerais no século XIX, ver: CRAVO, Télio Anísio. Por estradas e caminhos no interior do Brasil oitocentista: viajantes e o desenvolvimento da infraestrutura de transportes de Minas Gerais. Belo Horizonte: Universidade Federal de Minas Gerais, 2009 (História, Monografia de bacharelado).

2 As ferrovias significaram verdadeira revolução nos transportes e com transcendentes repercussões sociais e econômicas. Na história dos transportes, esse modal insere-se na Segunda Revolução dos Transportes, juntamente com a navegação a vapor. No contexto histórico da Segunda Revolução Industrial, as ferrovias possibilitaram aumento da velocidade e da qualidade do transporte de carga, barateando e incorporando novos produtos, como 
excetuadas as epopéicas iniciativas materializadas nos caminhos coloniais, ${ }^{3}$ caracteriza-se pela consideração quase que exclusiva de iniciativas pontuais. Sobretudo as experiências da União e Indústria - estrada pavimentada que ligava Juiz de Fora-MG a Petrópolis-RJ - e da estrada de Santa Clara - integrada ao projeto de colonização de Teófilo Otoni e que estabelecia articulação bi-modal ao longo do vale do Mucuri. ${ }^{4}$ Entretanto, essas duas estradas não espelham as características do conjunto da malha mineira e muito menos representam a forma como a rede viária foi mantida e expandida no transcurso do século XIX.

\section{Breves apontamentos sobre os transportes no período colonial mineiro}

Alguns aspectos contextuais são especialmente relevantes ao dimensionamento do desenho, extensão e características da malha viária sobre a qual atuou a administração provincial de Minas Gerais. No período colonial, no quadro da economia do ouro, a preocupação com o contrabando fez com que a Metrópole colocasse em prática política restritiva em relação aos caminhos, proibindo o uso de alguns e a abertura de novos. ${ }^{5}$ Por meio de reiteradas proibições, a Coroa buscou obstar o contrabando de ouro e pedras preciosas e garantir o pagamento de impostos nos registros. ${ }^{6}$ Foram impedidas as ligações por terra com a Bahia, a partir de 1701, e, após 1704, com o Espírito Santo.

A proibição de transportar bens pela estrada da Bahia data especificamente de 1696. No entanto, somente a partir do momento que Borba Gato, capitão-mor das Minas do Rio das Velhas, recebe, em outubro de 1701, carta régia reafirmando a proibição, é que começaram a se efetuar os confiscos

o minério e o carvão mineral. As estradas de ferro garantiram maior precisão nos horários, encurtaram distâncias e diminuíram custos; SILVEIRA, Márcio Rogério da. A importância geoeconômica das estradas de ferro no Brasil. Presidente Prudente: Universidade Estadual Paulista, 2003, p.66 (Geografia, Tese de doutorado).

3 Leitura obrigatória sobre os caminhos coloniais é a obra de ANTONIL, André João. Cultura e opulência do Brasil, por suas drogas e minas. Lisboa: Oficina Real Deslandesiana, 1711. Edição Fac-similar. Exemplo de trabalho acadêmico sobre os caminhos coloniais enquanto rotas de comércio: ZEMELLA, Mafalda. O abastecimento da capitania de Minas Gerais no século XVIII. São Paulo: Hucitec, 1990; COSTA, Antônio Gilberto (org.). Os caminhos do ouro e a Estrada Real. Belo Horizonte: Editora da Universidade Federal de Minas Gerais, 2005, traz descrição pormenorizada das rotas utilizadas no período colonial, bem como rico material cartográfico; PIMENTA, José Demerval. Caminhos de Minas Gerais. Belo Horizonte: Imprensa Oficial, 1971, é o trabalho com informações mais completas sobre as principais vias mineiras entre os períodos colonial e republicano.

4 A rodovia União e Indústria, aberta ao trânsito em 1861 e construída por Mariano Procópio Ferreira Lage, gerou grande impacto econômico na região da Mata, como se pode constatar em BLASENHEIM, Peter L. Uma história regional da Zona da Mata mineira - 1879/1906. In: Seminário de Estudos Mineiros. Belo Horizonte: PROED/UFMG, 1982; GIROLETTI, Domingos. A industrialização de Juiz de Fora. Juiz de Fora: Editora Universidade Federal de Juiz de Fora, 1988. Para a estrada de Santa Clara, ver: ARAÚJO, Valdei Lopes de. Teófilo Otoni e a Companhia do Vale do Mucury: a modernidade possível. Belo Horizonte: Secretaria de Estado de Cultura e Arquivo Público Mineiro, 2003; BENTO, Bruno Dias. As matrizes e a fundação: a Companhia de Commercio e Navegação do Mucury \& a estrada de ferro Bahia e Minas. Um breve estudo da formação do Vale do Mucuri. Belo Horizonte: Universidade Federal de Minas Gerais, 2006 (Ciências Sociais, Monografia de bacharelado).

5 ZEMELLA, Mafalda. O abastecimento da capitania de Minas Gerais no século XVIII, p.49.

6 CHAVES, Cláudia Maria das Graças. Perfeitos negociantes: mercadores das minas setecentistas. São Paulo: Annablume, 1999, p.74. 
prometidos. A interdição foi reiterada no Regimento das Minas de 1702, em que foi determinado que somente o gado seria permitido entrar, enquanto os escravos deveriam vir pelo porto do Rio de Janeiro. Entretanto, por meio de documentação gerada nos processos de confisco, fica evidente que havia trânsito na região, inclusive constam informações sobre os prováveis caminhos utilizados para atravessar esta parte do território de Minas Gerais: o de Maquiné e o das Macaúbas. As informações sugerem ainda a presença, ao longo desses caminhos, de estalagens para as tropas. ${ }^{7}$

Cunha Matos faz referência a alvarás que, em 1725 e 1727, proibiram a abertura de caminhos para Cuiabá e que determinavam que a rota a ser utilizada deveria ser a que partia de São Paulo. ${ }^{8}$

No caso do Espírito Santo, mesmo com repetidas proibições reais e promessas de punições sumárias, em 1728, o vice-rei Vasco Fernandes, após "ter noticiais de que ao norte do Rio Doce 'descobriram-se algumas esmeraldas de muita dureza e de cor muito clara' ao invés de proibir mandou em diligência Brás Cubas Leme, concedendo-lhe o título de 'superintendente de todas as minas que descobrir'". Deste modo, se, por um lado, é difícil dimensionar a eficácia dessas restrições, por outro, a inobediência, inclusive das próprias autoridades coloniais, é sugestiva do provável resultado do embate entre as forças das proibições reais e as do fascínio exercido pelas riquezas minerais. ${ }^{9}$ Lenharo ressalta que a legislação que proibia a abertura de novas estradas foi burlada por tropeiros e colonizadores e que, após a retirada das proibições, várias estradas já abertas e largamente utilizadas foram legalizadas. ${ }^{10}$

Também no que se refere à circulação interna buscou-se limitar a expansão da malha viária com o objetivo de facilitar a exação fiscal que recaía sobre o comércio de abastecimento. Contudo, as restrições não conseguiram impedir a abertura de atalhos, que eram constantemente criados para que a passagem pelos registros fosse evitada. ${ }^{11}$

A postura da Metrópole em relação à infra-estrutura viária de Minas Gerais só mudou depois da chegada da Corte no Rio de Janeiro, momento que a economia mineira já se estruturava em novas bases. A política joanina, orientada por projeto que objetivava a integração do centro-sul, ${ }^{12}$ significou, em linhas gerais, um corte na forma como foi tratada a infra-estrutura viária mineira. No início do século XIX, quando da instalação da Corte, os principais

7 CARRARA, Ângelo Alves. Agricultura e pecuária na capitania de Minas Gerais (1674 - 1807). Rio de Janeiro: Universidade Federal do Rio de Janeiro, 1997, p.102 (História Social, Tese de doutorado).

8 CUNHA MATOS, Raimundo José da. Corografia histórica da Província de Minas Gerais (1837). v.2, Minas Gerais: Publicações do Arquivo Público Mineiro, 1979, p.28.

9 ESPÍNDOLA, Haruf Salmem. Sertão do Rio Doce. Bauru/São Paulo: EDUSC, 2005, p.30.

10 LENHARO, Alcir. As tropas da moderação: o abastecimento da Corte na formação política do Brasil (1808-1842). São Paulo: Símbolo, 1979, p.59.

11 CHAVES, Cláudia Maria das Graças. Perfeitos negociantes, p.74.

12 LENHARO, Alcir. As tropas da moderação, p.57-61; PRADO JUNIOR, Caio. Formação do Brasil contemporâneo. São Paulo: Brasiliense, 1970, p.246. 
caminhos que respondiam pelo abastecimento da capital a partir de Minas Gerais ainda eram os mesmos que ligavam a cidade do Rio de Janeiro às zonas de mineração no século XVIII. ${ }^{13}$ Mormente o Caminho Novo e suas variantes: Caminho do Couto e Caminho de Terra. Assim, procedeu-se a revisão das proibições vigentes durante o Dezoito, foram abertos caminhos e/ou reconhecidos aqueles que eram utilizados ilegalmente pelos tropeiros.

Do período que antecede ao abordado neste estudo, portanto anterior a 1840, destacam-se duas heranças: i. a infra-estrutural, sobre a qual atuará o Governo Provincial, com o objetivo de assegurar a manutenção e expansão da malha viária; e ii. a administrativa, iniciada com a chegada da Corte, e que será aprimorada pela província no transcurso do período imperial.

\section{A Secretaria de Obras Públicas e as políticas de transportes de Minas Gerais}

Após o Ato Adicional de 1834, ${ }^{14}$ foi estabelecida em Minas Gerais a Secretaria de Obras Públicas, ${ }^{15}$ com a função geral de administrar todas as obras realizadas pelo Governo Provincial. Em meio ao movimento mais amplo de demarcação do campo de atuação político-administrativa da província, definiu-se que prover o espaço mineiro com estradas, caminhos e pontes transitáveis seria também atribuição do Governo Provincial, ${ }^{16}$ responsabilidade que, a partir de então, foi sistematicamente cumprida. É importante ressaltar que a somatória de diversos fatores, como a condição

13 LENHARO, Alcir. As tropas da moderação, p.58.

14 O Ato Adicional de agosto de 1834 representa importante reforma constitucional realizada no período regencial e que teve grandes repercussões nas províncias. Ele transformou os conselhos gerais provinciais em assembléias legislativas, instituiu a discriminação das rendas públicas gerais e provinciais, a divisão dos poderes tributários, manteve o município subordinado à província e a nomeação do presidente de província pelo Governo Central. COSTA, Emília Viotti da. Da Monarquia à República: momentos decisivos. São Paulo: Editora da UNESP, 1999, p.154 O Ato ampliou o número de representantes provinciais reunidos no âmbito do legislativo provincial. As assembléias ficaram responsáveis por auxiliar os presidentes na gestão administrativa sob sua jurisdição. GOUVÊIA, Maria de Fátima. O Império das províncias: Rio de Janeiro, 1822-1889. Rio de Janeiro: Civilização Brasileira, 2008, p.19.

15 Na realidade, ao longo dos anos, essa repartição teve várias denominações; MARTINS, Maria do Carmo Salazar. Anotações sobre a organização administrativa da província de Minas Gerais. Anais do VI Seminário sobre a economia mineira. Belo Horizonte: Universidade Federal de Minas Gerais, 1992. Optou-se por nomeá-la indistintamente Secretaria de Obras Públicas.

16 A legislação imperial que deu partida à divisão da responsabilidade entre as instâncias de governo com a construção e conservação da infra-estrutura viária determinava a seguinte regra geral: "que pertencerem a província da capital do Império, ou a mais de uma Província, serão promovidas pelo Ministro e Secretário de Estado dos Negócios do Império; as que forem de uma só província, pelos seus Presidentes em Conselho; e as que forem do termo de uma cidade, ou vila, pelas respectivas câmaras municipais"; LEI IMPERIAL DE 29/08/1828, Conjunto das Leis Imperiais do acervo do Arquivo Público Mineiro. No ano de 1865, o Visconde do Uruguai, ao tratar das obras públicas provinciais, afirmou: "sobre obras publlicas ainda nos achamos no embryão da lei, hoje obsoleta de 29/08/1828, tempo de tyrocinio e de inexperiência, anterior ao Acto Adicional". URUGUAl, Visconde de. Estudos Práticos sobre a administração das províncias do Brasil. v.ll, Rio de Janeiro: B. L. Garnier, Livreiro e Editor, 1865, p.77. Após o Ato Adicional de 1834, verifica-se também em Minas Gerais a criação de legislação que demarcaria as responsabilidades entre as instâncias provincial e municipal. BARBOSA, Lidiany Silva. Tropas e ferrovias em uma província não-exportadora: Estado, elites regionais e as contradições da política de transportes no início da modernização - Minas Gerais, 1835-1889. Rio de Janeiro: Universidade Federal do Rio de Janeiro, 2011, p.36-80 (História Social, Tese de doutorado). 
interior, o dinamismo econômico, ${ }^{17}$ a diversidade regional, ${ }^{18}$ a extensa rede de cidades, ${ }^{19}$ a ocupação territorial praticamente consolidada ${ }^{20}$ e o maior contingente populacional do Império, ${ }^{21}$ multiplicaram e tornaram crescentemente complexas as responsabilidades da Secretaria de Obras Públicas da província de Minas Gerais. ${ }^{22}$

Nestes termos, estradas e pontes passaram gradativamente a serem tratadas como objeto de políticas públicas. Dado o pressuposto, de validade histórica universal, de que dotar uma localidade, uma região ou um país com obras viárias permite manter ou ampliar a acessibilidade, em uma província com economia dinâmica e em expansão, sem acesso ao mar e na qual a circulação de pessoas e bens baseava-se, fundamentalmente, em tropas de muares ${ }^{23}$ serão notavelmente significativas as realizações públicas e privadas dessa natureza.

Considera-se ainda que o setor de transportes é essencial para o funcionamento de qualquer sistema econômico e que os seus serviços são, guardadas as adequações históricas, funcionais a todo tipo de unidade produtiva. ${ }^{24}$ No mesmo sentido, o padrão de distribuição de obras viárias tem, potencialmente, grande possibilidade de interferir na realidade. Entretanto, quando da análise de experiências históricas concretas é necessário fugir de compreensão simplista, que toma a presença de determinada infra-estrutura de transporte, por si só, como fator capaz e suficiente de gerar desenvolvimento na região onde foi implantada. Como alerta Berion, a relação do tipo "causa e efeito" não deve ser considerada tão direta no caso dos transportes. ${ }^{25}$ Há que se considerar inúmeros componentes da

17 MARTINS, Roberto Borges. A economia escravista de Minas Gerais no século XIX. Texto para discussão No. 10. Belo Horizonte: Universidade Federal de Minas Gerais, 1982.

18 GODOY, Marcelo Magalhães. Intrépidos viajantes e a construção do espaço: uma proposta de regionalização para as Minas Gerais do século XIX. Texto para discussão $n^{\circ}$. 109. Belo Horizonte: Universidade Federal de Minas Gerais, 1996.

19 RODARTE, Mario Marcos Sampaio. A pertinácia das minas que não se esgotaram. Belo Horizonte: Universidade Federal de Minas Gerais, 1999 (Economia, Dissertação de mestrado).

20 PAULA, João Antônio de. Raízes da modernidade em Minas Gerais. Belo Horizonte: Autêntica, 2000.

21 PAIVA, Clotilde Andrade. População e economia nas Minas Gerais do século XIX. São Paulo: Universidade de São Paulo, 1996 (História Social, Tese de doutorado).

22 Para análise do processo de institucionalização da repartição provincial que, no período de 1834 a 1889, administrou a construção e conservação da rede viária de Minas Gerais, ver: BARBOSA, Lidiany Silva. Tropas e ferrovias em uma província não-exportadora, p.37-64, que discute a dinâmica administrativa voltada para a construção e conservação das obras públicas viárias provinciais, as injunções políticas que interferiam na ação de governo e os atores envolvidos nessa imensa tarefa, especialmente os engenheiros.

23 Embora em Minas Gerais estejam importantes bacias hidrográficas do país, que definem rede hídrica fortemente capilarizada e com sentidos múltiplos, o potencial de integração econômica por meio hidroviário era pequeno pelas restrições à navegação e, principalmente, pelo lugar secundário que esta modalidade de transporte ocupou nas políticas viárias da província. WIRTH, John D. O fiel da balança: Minas Gerais na federação brasileira, 1889-1930. Rio de Janeiro: Paz e Terra, 1982, p.43.

24 BARAT, Josef. Evolução dos transportes no Brasil. Rio de Janeiro: IBGE/IPEA, 1978, p.4, p.100.

25 Ainda que Pascal Berion analise grandes infra-estruturas de transportes modernos (TGV e auto-estradas) de um país central (França) suas reflexões teóricas avançam questões importantes para os estudos dos transportes em geral, sobretudo no aspecto metodológico. BERION, Pascal. Analyser les mobilites et le rayonnement des villes pour reveler les effets territoriaux des grandes infrastructures de transport. Les Cahiers Scientifiques du Transport, n.33, p.109-127,1998 
realidade estudada, não apenas a forma como se deslocam pessoas e bens, essencial para o desenvolvimento de uma economia.

\section{Os Processos de Construção de Estradas e Pontes}

Os Processos de Construção de Estradas e os Processos de Construção de Pontes são conjuntos documentais gerados pela Secretaria de Obras Públicas e que compreendem informações sobre a dinâmica político-administrativa das intervenções viárias realizadas pela província no período 1840 a 1889. Possuem como principais atributos: i. o largo recorte temporal, ou aproximadamente meio século; ii. a extensa cobertura espacial, a compreender intervenções em todo o território de Minas Gerais efetivamente ocupado; iii. massa documental volumosa, mais de 24 mil documentos; iv. e grande diversidade temática, a compreender todas as etapas do processo de manutenção e construção da infra-estrutura viária. A função primeira dos Processos foi informar ao governo sobre o andamento das obras que receberam algum tipo de recurso financeiro da província. Trata-se, portanto, de documentação coeva às intervenções nas estradas e pontes, com registros de aspectos administrativos, financeiros, técnicos e sociais referentes às obras públicas viárias provinciais. ${ }^{26}$

A partir de inventário, que compreendeu a leitura e recolhimento de informações em todos os documentos dos Processos, foi elaborado banco de dados ${ }^{27}$ a permitir amplo estudo de múltiplos aspectos da estrutura e dinâmica das obras públicas viárias provinciais. A construção do banco de dados foi precedida da concepção de complexa metodologia de classificação das informações recolhidas nos Processos. Deste modo, dado o seu caráter, o banco de dados em si se constitui em resultado substantivo da pesquisa, para além do conhecimento que proporciona por meio da análise das freqüências e cruzamentos das informações que o compõem.

Este estudo está fortemente associado a pesquisas anteriores, as quais se filia e, de alguma maneira, complementa. Tais pesquisas, ainda que independentes e tematicamente distintas, partiram das mesmas orientações metodológicas e de comum compreensão da economia mineira oitocentista. Deste modo, é adotada a regionalização da província proposta por Godoy (ver Anexo), ${ }^{28}$ os níveis de desenvo/vimento econômico regionais elaborados

26 BARBOSA, Lidiany Silva. Tropas e ferrovias em uma província não-exportadora, p. 212-223.

27 Todos os aspectos técnicos e metodológicos referentes à construção do banco de dados são apresentados, detalhadamente, em Anexo constante em: BARBOSA, Lidiany Silva. Tropas e ferrovias em uma província nãoexportadora, p.314-349, inclusive com a explicação de todas as variáveis e o arrolamento completo de suas respectivas categorias.

28 A proposta de regionalização adotada baseou-se, exclusivamente, na percepção do espaço de viajantes estrangeiros que percorreram quase todo o território de Minas Gerais, na primeira metade do século XIX. Do inter-relacionamento de fatores físiográficos, demográficos, econômicos, administrativos e históricos logrou-se a divisão de Minas Gerais em 18 regiões GODOY, Marcelo Magalhães. Intrépidos viajantes e a construção do 
por Paiva ${ }^{29}$ e os dados demográficos e de extensão territorial sistematizados por Mello Filho, Santos Júnior e Rodarte. ${ }^{30}$ Por este atributo, a análise aqui apresentada estabeleceu comparações metodologicamente mais seguras e realizou exercícios mais amplos.

Opção metodológica específica a este estudo é o pressuposto de que a distribuição das intervenções viárias, portanto dos Processos e dos documentos correspondentes, pelo espaço mineiro se constitui em índice da distribuição regional dos recursos públicos da província voltados a infra-estrutura de transportes. ${ }^{31}$ Adicionalmente vale sublinhar o fato de inexistir dados disponíveis sobre as finanças públicas provinciais que sejam suficientemente seriados, abrangentes, sistematizados e regionalmente desagregados a permitir o acompanhamento do gasto público com obras viárias. ${ }^{32}$

Várias indagações são sugeridas pelos possíveis impactos da distribuição das obras viárias pelo território mineiro, sobretudo como tal distribuição pode ter atuado, no período em questão, no processo de diferenciação regional que remonta ao período colonial. ${ }^{33}$ As regiões onde estavam os maiores contingentes populacionais eram privilegiadas com maior número de intervenções provinciais? A regiões economicamente mais dinâmicas foram as mais capazes em carrear obras públicas provinciais? Prevaleceu correspondência entre a extensão territorial e a distribuição das obras pú-

espaço. A representação cartográfica em anexo contempla a regionalização, com a identificação e classificação das unidades regionais segundo o nível de desenvolvimento econômico.

29 As regiões foram classificadas segundo indicadores de desenvolvimento criados com base, principalmente, em relatos de viajantes estrangeiros. A autora ressalta a existência de "divisão do trabalho que se revelou mais intensa quando associada ou relacionada a alguma produção voltada para mercados externos, ou a núcleos urbanos de regiões tidas como desenvolvidas". PAIVA, Clotilde Andrade. População e economia nas Minas Gerais do século $X I X, p .159$.

30 MELLO FILHO, Marcelo S. B.; SANTOS JÚNIOR, José M.; RODARTE, Mario Marcos Sampaio. Nem desconcentração espacial, nem ruralização: o processo de ocupação demográfica, na província de Minas Gerais, entre as décadas de 1830 e 1870. XII Seminário sobre a Economia Mineira, 2006. Belo Horizonte: Universidade Federal de Minas Gerais, 2006.

31 BARBOSA, Lidiany Silva; GODOY, Marcelo Magalhães; MENDES, Philipe Scherrer. Transportes e finanças públicas: contribuição para o estudo do lugar do dispêndio em infra-estrutura viária nos orçamentos provinciais e municipais de Minas Gerais, 1835-1889. In: GOULARTI FILHO, Alcides; CIMÓ, Paulo Roberto (org.). Transportes e formação regional: contribuição à história dos transportes no Brasil. Dourados: Editora Universidade Federal da Grande Dourados, 2011, p.237-268.

32 Os dados das finanças públicas da província disponíveis (MENDES, Philipe Scherrer. Finanças públicas da província de Minas Gerais. Belo Horizonte: Universidade Federal de Minas Gerais, 2007 (Economia, Monografia de bacharelado) não apresentam nível de desagregação a permitir distribuição regional. Constam, sobretudo, nos Relatórios dos Presidentes da Província, nas Leis Mineiras e em avulsos da Fazenda Provincial. Para avaliação geral das finanças provinciais, ver também: IGLÉSIAS, Francisco. Política econômica do governo provincial mineiro, 1835-1889. Rio de Janeiro: Instituto Nacional do Livro, 1958.

33 Desde o início da ocupação do território, que se tornaria a capitania de Minas Gerais, começou a se esboçar diferenciação regional e "duas categorias de percepção geográfica já são identificadas: as minas e os sertões". A região das minas correspondia aos núcleos originais de ocupação e a dos sertões recobria a zona curraleira. Havia, no entanto, outros sertões cuja característica predominante até o início do século XIX era a de ser habitada por gentios; CARRARA, Ângelo Alves. Agricultura e pecuária na capitania de Minas Gerais (1674 - 1807). Renato Pinto Venâncio também propõe segmentação do espaço da capitania de Minas Gerais e reflete sobre a importância da fronteira; VENÂNCIO, Renato Pinto. Comércio e fronteira em Minas Gerais colonial. In: FURTADO, Júnia Ferreira (org.). Diálogos oceânicos. Belo Horizonte: Editora da UFMG, 2001, p.181-182. Com a desagregação da economia do ouro, aprofundou-se o processo de diferenciação regional iniciado no XVIII e que se consolidará no XIX; GODOY, Marcelo Magalhães. Intrépidos viajantes e a construção do espaço. 
blicas provinciais? As respostas a essas perguntas permitirão avançar nas discussões sobre o modus operandi da administração provincial de Minas Gerais para o setor dos transportes, sobre os transportes também como fator atuante na configuração regional mineira no Dezenove, além de contribuir para o aprofundamento da análise de período pouco conhecido da história dos transportes de Minas Gerais.

\section{Transportes, região e desenvolvimento econômico}

A avaliação da distribuição espacial dos Processos se constitui na primeira medida da importância regional das obras viárias. Dado o pressuposto de que a distribuição agregada dos Processos é medida da distribuição relativa dos recursos públicos destinados a obras viárias, nota-se relação direta entre o nível de desenvo/vimento econômico (NDE) regional e a incidência de obras viárias. ${ }^{34}$

O agregado de regiões com NDE alto responde por mais de quatro quintos $(84,5 \%)$ dos Processos. Enquanto o agregado de regiões com NDE médio e baixo somam menos de um quinto (15,5\%). Excetuado o caso da Mineradora Central Leste (MCLeste), que se constituía em fronteira de agropecuária dinâmica e com forte integração inter-regional, ${ }^{35}$ todas as regiões com maior número de Processos apresentavam NDE alto.

Três regiões espacialmente contíguas do centro-sul da província - Mineradora Central Oeste (MCOeste), Sudeste e Mata - respondem por quase dois terços dos Processos (64,8\%). Fato revelador da elevada concentração espacial das intervenções viárias provinciais e que se explica, fundamentalmente, pelo peso da polarização e expressão política da MCOeste, ${ }^{36}$ pela dinâmica econômica agroexportadora da Mata $^{37}$ e pela importância da economia de mercado interno e externo do Sudeste. ${ }^{38}$ Também é relevante destacar a localização geográfica dessas regiões, que concentravam a maior parte dos corredores viários que estabeleciam articulações interprovincias, além da posição de principal entroncamento viário desempenhado pela porção setentrional da região Sudeste.

Ponto notável é a discrepância da participação relativa das duas regiões do Sul Mineiro que, embora com o mesmo NDE, apresentam incidência

34 Foi necessário desenvolver metodologia específica para realizar a distribuição regional dos 452 Processos e dos 9.386 documentos correspondentes, referentes ao universo amostral que constitui a base de dados desse estudo. Para a metodologia adotada na constituição da amostra e na distribuição regional dos Processos e respectivos documentos, ver: BARBOSA, Lidiany Silva. Tropas e ferrovias em uma província não-exportadora, p.213-215, p.226229. A amostra é perfeitamente representativa do universo completo dos Processos de Construção de Estradas e Pontes.

35 GODOY, Marcelo Magalhães. Intrépidos viajantes e a construção do espaço.

36 RODARTE, Mario Marcos Sampaio. A pertinácia das minas que não se esgotaram.

37 OLIVEIRA, Mônica Ribeiro de. Cafeicultura Mineira: formação e consolidação - 1809-1870. Anais do IX Seminário Sobre a Economia Mineira. Diamantina: Universidade Federal de Minas Gerais, 2000

38 PAIVA, Clotilde Andrade. População e economia nas Minas Gerais do século XIX. 
de Processos muito distinta. A participação do Sudeste é quase 3 vezes superior à do Sul Central (23,0\% para 7,9\%), o que sugere fatores não econômicos a interferir na distribuição de recursos provinciais, mormente fatores políticos. Provavelmente a discrepância decorra da incapacidade das elites do Sul Central em arregimentar recursos públicos para a região, bem como da posição geográfica relativamente menos privilegiada do que a do Sudeste. Não é gratuito que da cidade de Campanha, a principal do Sul Central, ${ }^{39}$ partiram várias tentativas de provincialização da região, ${ }^{40}$ sendo o desprestígio ante à administração provincial a justificativa apresentada pelas elites locais. ${ }^{41}$ Constata-se, portanto, que os dados dos Processos estão em perfeita consonância com o argumento apresentado pelos coevos.

Três regiões apresentam, por razões distintas, percentuais proporcionalmente muito baixos de Processos e incompatíveis com o pertencimento ao agregado com NDE médio. O primeiro é o caso do Vale do Alto-Médio Rio São Francisco, que se explica pela franca hegemonia do modal navegação fluvial. Os outros dois, as regiões do Triângulo e Sudoeste, que se caracterizavam por se constituir em fronteira algo dinâmica da agropecuária, mas com fraca integração, ou sem vias de importância interregional a justificar intervenções provinciais. ${ }^{42}$

O cruzamento do número de processos com a extensão territorial das regiões ressalta ausência de relação de proporcionalidade. O agregado de regiões com NDE alto respondia por menos de um quarto do território $(22,9 \%)$ e mais de quatro quintos $(84,5 \%)$ dos processos. No outro extremo, está o agregado de regiões com NDE baixo, que cobriam mais da metade do território $(50,8 \%)$ e perfaziam apenas $5,5 \%$ dos processos.

Como medida de densidade de obras viárias no espaço, calculouse o número de processos por área de $1.000 \mathrm{Km}^{2}$. Excetuado o caso da MCLeste, apenas as regiões com NDE alto apresentaram valores superiores aos válidos para a totalidade da província, ou aproximadamente uma $(1,1)$ intervenção por $1.000 \mathrm{Km}^{2}$. A grande divergência dos valores confirma a forte assimetria na distribuição dos processos, inclusive internamente aos agregados regionais segundo o NDE. O grupo com NDE alto apresenta densidade quase 10 vezes superior ao de NDE médio $(3,89$ - 0,40) e 35 vezes maior do que o de NDE baixo $(3,89-0,11)$ (Tabela 1 ).

No caso das regiões com NDE alto, salientam os valores referentes a MCOeste, Mata e, principalmente, Sudeste, e pelas mesmas razões anteriormente comentadas. À elevada densidade espacial relativa de obras viárias dessas regiões correspondia malha viária mais extensa e complexa.

39 ANDRADE, Marcos Ferreira de. Elites regionais e a formação do Estado imperial brasileiro: Minas Gerais - Campanha da Princesa (1799-1850). Rio de Janeiro: Arquivo Nacional, 2008.

40 VALLADÃO, Alfredo. Campanha da Princeza, 1821-1909. v.ll, Rio de Janeiro: Leuzinger S.A., 1940, p.165-175.

41 WIRTH, John D. O fiel da balança, p.158.

42 PAIVA, Clotilde Andrade. População e economia nas Minas Gerais do século XIX. 
Tabela 1

Distribuição regional e densidade territorial dos Processos de Construção de Estradas e Pontes, Minas Gerais, 1840-1889

\begin{tabular}{|c|c|c|c|c|c|}
\hline \multirow{2}{*}{ Regiões } & \multicolumn{2}{|c|}{ Processos } & \multicolumn{2}{|c|}{ Extensão Territorial } & \multirow{2}{*}{$\begin{array}{c}\text { Processos por } \\
1.000 \mathrm{Km}^{2} \\
\end{array}$} \\
\hline & $\mathrm{N}^{0}$ & $\%$ & $\mathrm{Km}^{2}$ & $\%$ & \\
\hline Nível Alto de Desenvolvimento Econômico & 525 & 84,5 & 134.889 & 22,9 & 3,89 \\
\hline Diamantina & 27 & 4,3 & 14.968 & 2,7 & 1,80 \\
\hline Intermediária de Pitangui-Tamanduá & 46 & 7,4 & 24.573 & 4,4 & 1,87 \\
\hline Mineradora Central Oeste & 181 & 29,1 & 30.485 & 5,4 & 5,94 \\
\hline Mata & 79 & 12,7 & 23.415 & 4,2 & 3,37 \\
\hline Sudeste & 143 & 23,0 & 15.926 & 2,8 & 8,98 \\
\hline Sul Central & 49 & 7,9 & 25.522 & 4,5 & 1,92 \\
\hline Nível Médio de Desenvolvimento Econômico & 62 & 10,0 & 154.620 & 26,3 & 0,40 \\
\hline Vale do Alto-Médio Rio São Francisco & 1 & 0,2 & 11.792 & 2,1 & 0,08 \\
\hline Triângulo & 1 & 0,2 & 56.506 & 10,0 & 0,02 \\
\hline Araxá & 11 & 1,8 & 28.378 & 5,0 & 0,39 \\
\hline Vale do Médio-Baixo Rio das Velhas & 8 & 1,3 & 16.815 & 3,0 & 0,48 \\
\hline Mineradora Central Leste & 36 & 5,8 & 26.301 & 4,7 & 1,37 \\
\hline Sudoeste & 5 & 0,8 & 14.828 & 2,6 & 0,34 \\
\hline Nível Baixo de Desenvolvimento Econômico & 34 & 5,5 & $298.874^{*}$ & 50,8 & 0,11 \\
\hline Sertão & 8 & 1,3 & 30.804 & 5,5 & 0,26 \\
\hline Minas Novas & 12 & 1,9 & 76.486 & 13,6 & 0,16 \\
\hline Paracatu & 1 & 0,2 & 62.147 & 11,0 & 0,02 \\
\hline Sertão do Alto Rio São Francisco & 7 & 1,1 & 44.174 & 7,9 & 0,16 \\
\hline Sertão do Rio Doce & 6 & 1,0 & 59.362 & 10,6 & 0,10 \\
\hline Minas Gerais & 621 & 100 & 562.482 & 100 & 1,10 \\
\hline
\end{tabular}

Fontes: Arquivo Público Mineiro (APM), SPOP 3/6: Seção Provincial, Obras Públicas, Processos de Construção de Estradas e Pontes, caixas 2 a 12 e 32 a 39

Notas: * Inclusive o território da região do Extremo Noroeste, sem freqüência de processos de obras viárias. Dados sobre a extensão territorial das regiões foram recolhidos em MELLO FILHO, Marcelo S. B.; SANTOS JÚNIOR, José M.; RODARTE, Mario Marcos Sampaio. Nem desconcentração espacial, nem ruralização: o processo de ocupação demográfica, na província de Minas Gerais, entre as décadas de 1830 e 1870. XII Seminário sobre a Economia Mineira, 2006. Belo Horizonte: Universidade Federal de Minas Gerais, 2006, p.15.

A distribuição espacial dos documentos se constitui na segunda medida da importância regional das obras viárias. Também aqui se considera o pressuposto de que a distribuição agregada dos documentos é medida da distribuição relativa dos recursos públicos destinados a obras viárias 
e permite, por decorrência, aferir quais regiões detinham maior capacidade em angariar esses recursos. Trata-se de medida mais refinada que a primeira por contemplar o peso relativo das intervenções (Processos). A primeira medida considera em plano de igualdade todas as intervenções, a segunda considera o peso proporcional de cada intervenção segundo o número de documentos elaborados.

Como no caso dos Processos de obras viárias, constata-se relação direta entre o NDE regional e a incidência de documentos das obras viárias. Assim, o agregado de regiões com NDE alto responde por bem mais de quatro quintos $(87,8 \%)$ dos documentos, enquanto os agregados de regiões com NDE médio e baixo por pouco mais de um décimo (12,2\%). Todas as regiões com maior número de documentos apresentavam NDE alto. Excetuados os casos das regiões de Araxá, com pecuária de mercado interno dinâmica, Minas Novas, com ocupação parcialmente antiga e atividade de mercado externo conjunturalmente relevante (algodão) e, principalmente, a Mineradora Central Leste, com fronteira agropecuária dinâmica e forte integração inter-regional. ${ }^{43}$

Três regiões espacialmente contíguas do centro-sul de Minas Gerais (MCOeste, Sudeste e Mata) respondem por mais de dois terços dos documentos (72,2\%), a revelar elevada concentração espacial das intervenções, e pelas mesmas razões anteriormente comentadas. Especialmente destacável é o caso da MCOeste que responde, sozinha, por praticamente um terço $(33,2 \%)$ dos documentos, a salientar a persistência da importância do antigo núcleo minerador ${ }^{44} \mathrm{e}$, certamente, a eficácia de sua elite política em arregimentar recursos. Mais uma vez, fica em evidência a discrepância da participação relativa das duas regiões do Sul Mineiro que, embora apresentem o mesmo NDE, figuram com incidência de documentos muito distinta. A participação do Sudeste é mais de 5 vezes superior a do Sul Central (24,9\% para 4,9\%). Medida mais refinada, a distribuição regional dos documentos amplia, sobremaneira, a distância entre o Sudeste e o Sul Central, ou seja, 3 vezes mais Processos para 5 vezes mais documentos. Notável divergência já que a extensão territorial do Sul Central era 60\% superior a do Sudeste e a população $30 \%$ maior!

Assim como no caso da distribuição dos processos, ainda que em patamares relativamente mais baixos, quatro regiões com NDE médio apresentam percentuais proporcionalmente reduzidos de documentos. $O$ primeiro é o caso do Vale do Alto-Médio Rio São Francisco, que se explica, como referido, pela franca hegemonia do modal navegação fluvial. Já a

43 PAIVA, Clotilde Andrade; GODOY, Marcelo Magalhães. Território de contrastes: economia e sociedade das Minas Gerais do século XIX. In: SILVA, Francisco Carlos Teixeira da; MATTOS, Hebe Maria; FRAGOSO, João Ribeiro (orgs.). Escritos sobre a história e educação: homenagem a Maria Yedda Leite Linhares. Rio de Janeiro: Maud/ Faperj, 2001.

44 RODARTE, Mario Marcos Sampaio. A pertinácia das minas que não se esgotaram. 
situação do Vale do Médio-Baixo Rio das Velhas se justifica, em parte, pela mesma razão, somado ao peso da localização geográfica divorciada do grande corredor de ligação do norte ao centro da província, ou ao longo da Serra do Espinhaço. ${ }^{45}$ Os casos das regiões do Triângulo e Sudoeste se explicam pelas razões anteriormente comentadas.

O cruzamento da distribuição regional do número de documentos com a da população na década de 1830 também evidencia a ausência de relação de proporcionalidade. O agregado de regiões com NDE alto respondia por dois terços da população $(66,7 \%)$ e um terço a mais dos documentos $(87,8 \%)$. O agregado de regiões com NDE médio perfazia pouco menos de um quinto da população $(19,8 \%)$ e respondia por parcela $60 \%$ menor dos documentos $(7,9 \%)$. O agregado de regiões com NDE baixo apresentava proporção de documentos três vezes menor do que a correspondente população (4,3\% para 13,4\%). Em síntese, reitera-se o caráter desigual da distribuição das intervenções provinciais em obras viárias, entenda-se dos recursos públicos.

Como medida de densidade de obras viárias pelo tamanho da população, calculou-se o número de documentos por 1.000 habitantes. Os valores referentes aos agregados, segundo o NDE, confirmam a forte assimetria na distribuição das obras viárias. Com o grupo com NDE alto com densidade mais de 3 vezes superior ao de NDE médio $(19,8-6,0)$ e 4 vezes maior do que o de NDE baixo $(19,8-4,9)$ (Tabela 2).

A grande divergência dos valores regionais reafirma a forte assimetria na distribuição dos documentos, inclusive internamente aos agregados segundo o NDE. No caso das regiões com NDE alto, salientam os valores referentes a MCOeste e, principalmente, Mata e Sudeste, que se explicam pelas razões já comentadas. À elevada densidade de documentos em relação à população dessas três regiões correspondia, portanto, malha viária mais extensa e complexa. O caso da região do Sertão do Rio Doce não deve ser considerado, posto a pronunciada subrepresentação da população regional em $1830 .{ }^{46}$

45 GODOY, Marcelo Magalhães. Intrépidos viajantes e a construção do espaço.

46 PAIVA, Clotilde Andrade. População e economia nas Minas Gerais do século XIX. 
Tabela 2

Distribuição regional e densidade demográfica dos documentos dos Processos de Construção de Estradas e Pontes, Minas Gerais, 1840-1889

\begin{tabular}{|c|c|c|c|c|c|}
\hline \multirow{2}{*}{ Regiões } & \multicolumn{2}{|c|}{ Documentos } & \multicolumn{2}{|c|}{ População em 1830} & \multirow{2}{*}{$\begin{array}{l}\text { Documentos por } \\
1.000 \text { habitantes }\end{array}$} \\
\hline & $\mathrm{N}^{0}$ & $\%$ & $\mathrm{~N}^{0}$ & $\%$ & \\
\hline Nível Alto de Desenvolvimento Econômico & 9.677 & 87,8 & 487.669 & 66,7 & 19,8 \\
\hline Diamantina & 237 & 2,1 & 29.949 & 4,1 & 7,91 \\
\hline Intermediária de Pitangui-Tamanduá & 938 & 8,5 & 83.949 & 11,5 & 11,17 \\
\hline Mineradora Central Oeste & 3.657 & 33,2 & 170.218 & 23,3 & 21,48 \\
\hline Mata & 1.560 & 14,1 & 43.897 & 6,0 & 35,54 \\
\hline Sudeste & 2.747 & 24,9 & 69.098 & 9,5 & 39,76 \\
\hline Sul Central & 538 & 4,9 & 90.588 & 12,4 & 5,94 \\
\hline Nível Médio de Desenvolvimento Econômico & 872 & 7,9 & 144.828 & 19,8 & 6,0 \\
\hline Vale do Alto-Médio Rio São Francisco & 5 & 0,0 & 14.160 & 1,9 & 0,35 \\
\hline Triângulo & 34 & 0,3 & 10.287 & 1,4 & 3,31 \\
\hline Araxá & 242 & 2,2 & 22.006 & 3,0 & 11,00 \\
\hline Vale do Médio-Baixo Rio das Velhas & 74 & 0,7 & 37.040 & 5,1 & 2,00 \\
\hline Mineradora Central Leste & 493 & 4,5 & 33.619 & 4,6 & 14,66 \\
\hline Sudoeste & 24 & 0,2 & 27.716 & 3,8 & 0,87 \\
\hline Nível Baixo de Desenvolvimento Econômico & 478 & 4,3 & 98.251 & 13,4 & 4,9 \\
\hline Sertão & 71 & 0,6 & 8.726 & 1,2 & 8,14 \\
\hline Minas Novas & 214 & 1,9 & 60.800 & 8,3 & 3,52 \\
\hline Paracatu & 1 & 0,0 & 10.152 & 1,4 & 0,10 \\
\hline Sertão do Alto Rio São Francisco & 78 & 0,7 & 18.306 & 2,5 & 4,26 \\
\hline Sertão do Rio Doce & 114 & 1,0 & 267 & 0,0 & 426,97 \\
\hline Minas Gerais & 11.027 & 100 & 730.778 & 100 & 15,09 \\
\hline
\end{tabular}

Fontes: APM, SPOP 3/6: Seção Provincial, Obras Públicas, Processos de Construção de Estradas e Pontes, caixas 2 a 12 e 32 a 39. APM, Seção Provincial, Presidência da Província, SPPP 1/10 e MP, diversas caixas. Censo de 1831/32.

Nota: Dados populacionais recolhidos em GODOY, Marcelo Magalhães. No país das minas de ouro a paisagem vertia engenhos de cana e casas de negócio: um estudo das atividades agroaçucareiras tradicionais mineiras, entre o Setecentos e o Novecentos, e do complexo mercantil da província de Minas Gerais. São Paulo: Universidade de São Paulo, 2004, p.245 (História Econômica, Tese de doutorado). 
A inexpressividade da parcela da documentação dos Processos referente à década de 1840 , apenas $(1,2 \%)$, resulta na concentração nas décadas de 1850 a 1880. ${ }^{47}$ Assim, por decorrência, os dados demográficos para a década de 1870 (Censo de 1872) estão em posição privilegiada para a comparação entre a distribuição regional dos documentos e da população. Dito em outros termos, em ponto médio do período de cobertura dos Processos.

Entre as décadas de 1830 e 1870 desenrolou-se significativa redistribuição relativa da população de Minas Gerais. Excetuada a Mata, com expressiva expansão que a lançou da $6^{\mathrm{a}}$ para a $2^{\mathrm{a}}$ mais populosa região da província, todas as regiões com NDE alto conheceram redução da participação relativa na população provincial entre as décadas de 1830 e 1870. A contrapartida foi o crescimento da participação relativa de quase todas as regiões com NDE médio e baixo. Trata-se de movimento de desconcentração populacional e alargamento da fronteira em todas as direções. Assim sendo, cresce substantivamente a participação relativa da população dos agregados de regiões com NDE médio e baixo e decresce o do agregado de regiões com NDE alto. ${ }^{48}$

Em termos provinciais, entre as décadas de 1830 e 1870, a taxa anual de crescimento foi superior a média nacional. A população de Minas Gerais quase chega a triplicar em 40 anos $^{49}$. Trata-se de expansão demográfica que espelha o dinamismo econômico da província, especialmente notável pelo fato de Minas apresentar o maior sistema escravista regional do país na década de $1870 . .^{50}$

O cruzamento da distribuição regional do número de documentos com a da população da década de 1870 evidencia, ainda mais que quando referido na população da década de 1830, a ausência de relação de proporcionalidade. O agregado de regiões com NDE alto apresenta proporção de documentos quase $50 \%$ maior do que o correspondente percentual de população (87,8\% para 59,7\%). Portanto, a elevada concentração de obras viárias em determinadas regiões resultava, fundamentalmente, do dinamismo econômico. Conquanto se observe divergências regionais importantes.

A relação documentos-população é praticamente proporcional para a região de Diamantina (2,1\% para $2,2 \%$ ), que passa por processo de perda de substância econômica entre a primeira e a segunda metade do século XIX (tomada como referência a população de 1830, a relação documentospopulação era de $2,1 \%$ para $4,1 \%)$. Próximo de proporcional para a região Intermediária de Pitangui-Tamanduá (8,5\% para $7,7 \%)$ e para a Mata $(14,1 \%$

47 BARBOSA, Lidiany Silva. Tropas e ferrovias em uma província não-exportadora, p.240-247.

48 MELLO FILHO, Marcelo S. B.; SANTOS JÚNIOR, José M.; RODARTE, Mario Marcos Sampaio. Nem desconcentração espacial, nem ruralização.

49 MELLO FILHO, Marcelo S. B.; SANTOS JÚNIOR, José M.; RODARTE, Mario Marcos Sampaio. Nem desconcentração espacial, nem ruralização.

50 MARTINS, Roberto Borges. A economia escravista de Minas Gerais no século XIX. 
para 13,6\%). No primeiro caso revela dinamismo econômico e carreamento de recursos proporcional. No segundo a proporção seria insuficiente, posto o forte dinamismo econômico da agroexportação cafeeira matense, a exigir mais do que proporcional intervenção na forma de obras viárias. A compensação estaria na expansão ferroviária concentrada na Mata, ${ }^{51}$ modal não contemplada pelos Processos de Construção de Estradas e Pontes.

A relação documentos-população é acentuadamente desproporcional para o Sul Central, com percentual de documentos que não alcança a metade do referente à população (4,9\% - 11,3\%). Conquanto permaneça região economicamente vigorosa na segunda metade do século XIX, ${ }^{52}$ OS dados novamente convergem, de forma inequívoca, para a incapacidade das elites regionais em arregimentar recursos para obras viárias. A posição desprivilegiada do Sul Central como destino de recursos para obras viárias, estratégicos para o desenvolvimento, se coaduna com a permanente reivindicação dos representantes regionais na Assembléia Provincial, bem como com a inclinação separatista da região na segunda metade do século XIX, que se queria legitimada em boa medida pelos desequilíbrios fiscais vigentes. ${ }^{53}$

A desproporção para as regiões Mineradora Central Oeste e Sudeste era em sentido oposto. Com acentuado desequilíbrio da documentação, percentualmente muito mais expressiva do que a respectiva participação relativa da população. Ainda mais notável por se tratarem de regiões que também se beneficiaram significativamente da expansão ferroviária até o final do Império. ${ }^{54}$ Muito provavelmente, aos fatores econômicos somaram-se os de ordem política para explicar a concentração das intervenções nessas duas regiões, que respondiam por praticamente um quarto da população $(24,9 \%)$ e enfeixavam bem mais da metade dos documentos $(58,1 \%)$. A proporção de documentos para a MCOeste era quase o dobro da respectiva população (33,2\% para 17,9\%). Já a proporção de documentos para o Sudeste era mais de duas vezes e meia a da respectiva população (24,9\% para $7,0 \%)$.

As regiões com NDE médio perfaziam pouco menos de um quarto da população $(23,1 \%)$ e, por outro lado, respondiam por parcela $66 \%$ menor dos documentos (7,9\%). Nenhuma das regiões com NDE médio respondeu por parcela de documentos superior a correspondente proporção de população. Regiões com NDE baixo apresentavam proporção de documentos quatro vezes menor do que a correspondente população (4,3\% para 17,2\%).

51 BATISTA, Felipe de Alvarenga. O mito da modernização pelos trilhos: a "era ferroviária" em Minas Gerais, $1850-$ 1940. Belo Horizonte: Universidade Federal de Minas Gerais, 2010 (Economia, Monografia de bacharelado).

52 MELLO FILHO, Marcelo S. B.; SANTOS JÚNIOR, José M.; RODARTE, Mario Marcos Sampaio. Nem desconcentração espacial, nem ruralização.

53 DULCl, Otávio Soares. Política e recuperação econômica em Minas Gerais. Belo Horizonte: Editora UFMG, 1999.

54 BLASENHEIM, Peter L. As ferrovias de Minas Gerais no século dezenove. Locus: Revista de História. Juiz de Fora, v.2, n.2, 1996; BATISTA, Felipe de Alvarenga, O mito da modernização pelos trilhos. 
Como medida de densidade de obras viárias pelo tamanho da população, calculou-se o número de documentos por 1.000 habitantes. Os valores referentes aos agregados segundo o NDE novamente confirmam forte assimetria. Com o grupo com NDE alto com densidade mais de 4 vezes superior ao de NDE médio $(7,8$ para 1,8$)$ e 6 vezes maior do que o de NDE baixo $(7,8$ para 1,3$)$ (Tabela 3).

Apenas quatro regiões com NDE alto apresentaram valores superiores aos válidos para a totalidade da província, ou mais de 5,3 documentos por 1.000 habitantes. São notáveis os casos da MCOeste, com quase o dobro da média provincial $(9,8 \%)$ e, principalmente, do Sudeste, com mais de três vezes e meia (19,0\%). Portanto, a coadunar-se com as razões anteriormente salientadas para explicar a concentração de intervenções. Como já destacado, à elevada densidade de documentos em relação à população dessas regiões é reveladora da existência de malha viária mais extensa e complexa. Igualmente destacável é o caso da região Sul Central, que detinha densidade de obras viárias quase três vezes e meia menor do que a média das regiões com NDE alto.

Para as regiões dos agregados com NDE médio e baixo constatou-se também divergências acentuadas. Como a das regiões contíguas de Araxá e Triângulo, com quase três vezes superior a densidade da primeira em relação a da segunda $(2,2$ para 0,8$)$.

O cruzamento do número de documentos com a extensão territorial das regiões ressalta, como no caso do cruzamento com o número de Processos, a ausência de relação de proporcionalidade. O agregado de regiões com NDE alto respondia por menos de um quarto do território $(22,9 \%)$ e bem mais de quatro quintos $(87,8 \%)$ dos documentos. No outro extremo, o agregado de regiões com NDE baixo cobriam mais da metade do território $(50,8 \%)$ e perfaziam apenas $4,3 \%$ dos documentos.

Como a realização de obras é um indicador de gasto público provincial, a elevada concentração das intervenções no transcurso de cinco décadas ressalta a desproporção regional do dispêndio público em obras viárias. Desproporção ainda mais acentuada se considerado os assinalados movimentos de desconcentração populacional e econômico entre a primeira e a segunda metade do século XIX.

Entre as regiões com NDE alto vigorava importante diferenciação na relação do número de documentos com a extensão territorial. Para duas regiões, Sul Central e Diamantina, prevaleceu certo equilíbrio, ou o dinamismo econômico não se traduziu no carreamento mais do que proporcional de recursos para obras viárias. Para os demais casos do agregado com NDE alto verificou-se incidência mais que proporcional de documentos sobre obras viárias. Para a Intermediária de Pitangui-Tamanduá, com percentual de documentos 2 vezes maior que a extensão territorial, Mata, com mais de 3 vezes superior, e MCOeste, com 6 vezes maior. Notável o caso do 
Sudeste, que apresentou percentual de documentos 9 vezes maior do que a correspondente extensão territorial. As razões para essas pronunciadas distinções foram discutidas anteriormente.

\section{Tabela 3}

Distribuição regional e densidade demográfica dos documentos dos Processos de Construção de Estradas e Pontes, Minas Gerais, 1840-1889

\begin{tabular}{|c|c|c|c|c|c|}
\hline \multirow{2}{*}{ Regiões } & \multicolumn{2}{|c|}{ Documentos } & \multicolumn{2}{|c|}{ População em 1870} & \multirow{2}{*}{$\begin{array}{l}\text { Documentos por } \\
1.000 \text { habitantes }\end{array}$} \\
\hline & $\mathrm{N}^{0}$ & $\%$ & $N^{0}$ & $\%$ & \\
\hline Nível Alto de Desenvolvimento Econômico & 9.677 & 87,8 & 1.243 .838 & 59,7 & 7,78 \\
\hline Diamantina & 237 & 2,1 & 46.604 & 2,2 & 5,09 \\
\hline Intermediária de Pitangui-Tamanduá & 938 & 8,5 & 160.680 & 7,7 & 5,84 \\
\hline Mineradora Central Oeste & 3.657 & 33,2 & 372.928 & 17,9 & 9,81 \\
\hline Mata & 1.560 & 14,1 & 282.452 & 13,6 & 5,52 \\
\hline Sudeste & 2.747 & 24,9 & 144.860 & 7,0 & 18,96 \\
\hline Sul Central & 538 & 4,9 & 236.314 & 11,3 & 2,28 \\
\hline Nível Médio de Desenvolvimento Econômico & 872 & 7,9 & 481.773 & 23,1 & 1,81 \\
\hline Vale do Alto-Médio Rio São Francisco & 5 & 0,0 & 30.843 & 1,5 & 0,16 \\
\hline Triângulo & 34 & 0,3 & 42.069 & 2,0 & 0,81 \\
\hline Araxá & 242 & 2,2 & 109.895 & 5,3 & 2,20 \\
\hline Vale do Médio-Baixo Rio das Velhas & 74 & 0,7 & 68.950 & 3,3 & 1,07 \\
\hline Mineradora Central Leste & 493 & 4,5 & 149.158 & 7,2 & 3,31 \\
\hline Sudoeste & 24 & 0,2 & 80.858 & 3,9 & 0,30 \\
\hline Nível Baixo de Desenvolvimento Econômico & 478 & 4,3 & 357.934 & 17,2 & 1,34 \\
\hline Sertão & 71 & 0,6 & 36.886 & 1,8 & 1,92 \\
\hline Minas Novas & 214 & 1,9 & 212.147 & 10,2 & 1,01 \\
\hline Paracatu & 1 & 0,0 & 34.398 & 1,7 & 0,03 \\
\hline Sertão do Alto Rio São Francisco & 78 & 0,7 & 74.503 & 3,6 & 1,05 \\
\hline Sertão do Rio Doce & 114 & 1,0 & --- & 0,0 & --- \\
\hline Minas Gerais & 11.027 & 100 & 2.083 .545 & 100 & 5,29 \\
\hline
\end{tabular}

Fontes: APM, SPOP 3/6: Seção Provincial, Obras Públicas, Processos de Construção de Estradas e Pontes, caixas 2 a 12 e 32 a 39.

Nota: Dados populacionais recolhidos em MELLO FILHO, Marcelo S. B.; SANTOS JÚNIOR, José M.; RODARTE, Mario Marcos Sampaio. Nem desconcentração espacial, nem ruralização, p.15. 
Quadro diametralmente oposto é o observado nas regiões com NDE médio e baixo, em que nenhuma região logrou percentual de documentos superior ao correspondente de extensão territorial. Conseqüentemente, nota-se generalizada incapacidade, mesmo para as regiões com NDE intermediário ou médio, de atrair recursos públicos minimamente correspondentes ao peso relativo da extensão territorial regional. Como o caso do Triângulo, que detinha $10,0 \%$ da área da província e respondeu por apenas 0,3\% dos documentos, de Minas Novas, com 13,6\% e 1,9\% respectivamente, de Paracatu, com $11,0 \%$ do território e apenas um documento $(0,009 \%)$, e do Sertão do Rio Doce, com 10,6\% e 1,0\% respectivamente. Quando somadas, as 4 regiões correspondiam a quase metade da área de Minas $(45,2 \%)$ e alcançavam a irrisória quantidade de 3,2\% dos documentos. Portanto, são evidências incontrastáveis da assimetria na distribuição das obras viárias provinciais e, por decorrência, dos recursos que lhe davam suporte.

Como medida de densidade de obras viárias no espaço, calculou-se o número de documentos por área de $1.000 \mathrm{Km} 2$. Os valores referentes aos agregados segundo o NDE reafirmam, de forma ampliada, a forte desproporção constatada para a mesma medida com base na distribuição dos Processos. Assim, o grupo com NDE alto apresenta densidade quase 12 vezes superior ao de NDE médio $(7,17$ para 0,56$)$ e próximo de 45 vezes maior do que o de NDE baixo $(7,17$ para 0,16) (Tabela 4).

Apenas as regiões com NDE alto, excetuado Diamantina, apresentaram valores superiores aos válidos para a totalidade da província, ou dois documentos por $1.000 \mathrm{Km} 2$. A grande divergência dos valores confirma a forte assimetria na distribuição dos documentos, inclusive internamente aos agregados regionais segundo o NDE. No caso das regiões com NDE alto, salientam os valores referentes a MCOeste, Mata e, principalmente, Sudeste, e pelas mesmas razões antes discutidas.

Os Processos de Construção de Estradas e Pontes contemplam intervenções circunscritas a um único espaço regional, portanto obras viárias intrarregionais, e intervenções respeitantes a duas ou três regiões, por conseguinte obras viárias interregionais. Não é possível demarcar exaustivamente, entenda-se todos, os Processos e respectivos documentos referentes aos dois tipos de intervenções. Não é possível pela recorrência de obras que, ainda que contemplem vias que articulam distintas regiões, apresentam-se nos Processos de Construção de Estradas e Pontes segmentadas em seções separadas em mais de um processo. Ainda assim, foram identificados 72 Processos e 1.223 documentos - respectivamente 16\% e 13\% do universo amostral - que contemplam obras viárias interregionais. Segundo a metodologia adotada, os 72 Processos foram desdobrados em 171 e os 1.223 documentos foram desdobrados em 2.942, com o lançamento duas ou três vezes segundo o número de regiões contempladas. 
Tabela 4

Distribuição regional e densidade territorial dos documentos dos Processos de Construção de Estradas e Pontes, Minas Gerais, 1840-1889

\begin{tabular}{|c|c|c|c|c|c|}
\hline \multirow[b]{2}{*}{ Regiões } & \multicolumn{2}{|c|}{ Documentos } & \multicolumn{2}{|c|}{ Extensão Territorial } & \multirow{2}{*}{$\begin{array}{c}\text { Documentos } \\
\text { por } \\
1.000 \mathrm{Km}^{2}\end{array}$} \\
\hline & $\mathrm{N}^{0}$ & $\%$ & $\mathrm{Km}^{2}$ & $\%$ & \\
\hline Nível Alto de Desenvolvimento Econômico & 9.677 & 87,8 & 134.889 & 22,9 & 7,17 \\
\hline Diamantina & 237 & 2,1 & 14.968 & 2,7 & 1,58 \\
\hline Intermediária de Pitangui-Tamanduá & 938 & 8,5 & 24.573 & 4,4 & 3,82 \\
\hline Mineradora Central Oeste & 3.657 & 33,2 & 30.485 & 5,4 & 12,00 \\
\hline Mata & 1.560 & 14,1 & 23.415 & 4,2 & 6,66 \\
\hline Sudeste & 2.747 & 24,9 & 15.926 & 2,8 & 17,25 \\
\hline Sul Central & 538 & 4,9 & 25.522 & 4,5 & 2,11 \\
\hline Nível Médio de Desenvolvimento Econômico & 872 & 7,9 & 154.620 & 26,3 & 0,56 \\
\hline Vale do Alto-Médio Rio São Francisco & 5 & 0,0 & 11.792 & 2,1 & 0,04 \\
\hline Triângulo & 34 & 0,3 & 56.506 & 10,0 & 0,06 \\
\hline Araxá & 242 & 2,2 & 28.378 & 5,0 & 0,85 \\
\hline Vale do Médio-Baixo Rio das Velhas & 74 & 0,7 & 16.815 & 3,0 & 0,44 \\
\hline Mineradora Central Leste & 493 & 4,5 & 26.301 & 4,7 & 1,87 \\
\hline Sudoeste & 24 & 0,2 & 14.828 & 2,6 & 0,16 \\
\hline Nível Baixo de Desenvolvimento Econômico & 478 & 4,3 & $298.874^{*}$ & 50,8 & 0,16 \\
\hline Sertão & 71 & 0,6 & 30.804 & 5,5 & 0,23 \\
\hline Minas Novas & 214 & 1,9 & 76.486 & 13,6 & 0,28 \\
\hline Paracatu & 1 & 0,0 & 62.147 & 11,0 & 0,00 \\
\hline Sertão do Alto Rio São Francisco & 78 & 0,7 & 44.174 & 7,9 & 0,18 \\
\hline Sertão do Rio Doce & 114 & 1,0 & 59.362 & 10,6 & 0,19 \\
\hline Minas Gerais & 11.027 & 100 & 562.482 & 100 & 1,96 \\
\hline
\end{tabular}

Fontes: APM, SPOP 3/6: Seção Provincial, Obras Públicas, Processos de Construção de Estradas e Pontes, caixas 2 a 12 e 32 a 39.

Notas: * Inclusive o território da região do Extremo Noroeste, sem freqüência de Processos de obras viárias. Dados sobre a extensão territorial das regiões foram recolhidos em MELLO FILHO, Marcelo S. B.; SANTOS JÚNIOR, José M.; RODARTE, Mario Marcos Sampaio. Nem desconcentração espacial, nem ruralização, p.15. 
As obras viárias interregionais estavam fortemente concentradas nas regiões com NDE alto, em patamares superiores aos correspondentes para todas as obras. O agregado de regiões com NDE alto respondia por $84,5 \%$ dos Processos em geral e $86,0 \%$ dos Processos referentes a obras em vias com cobertura interregional. Portanto, diferença pouco expressiva $(+1,8 \%)$. Entretanto, quando comparados os percentuais para documentos, a diferença aumenta, passa de 87,8\% para 94,5\% (+7,6\%).

Sob o ângulo das regiões com NDE médio e baixo, a participação relativa das obras viárias interregionais apresenta pronunciada divergência se comparada com a participação em geral. O agregado de regiões com NDE médio respondeu por 10\% dos Processos em geral e 8,8\% dos Processos referentes a obras interregionais, redução de $12 \%$, e por $7,9 \%$ dos documentos em geral e 2,8\% dos documentos relativos a obras interregionais, com expressiva redução de $65 \%$. Os valores correspondentes para o agregado de regiões com NDE baixo salientam pequena diferença quanto aos Processos (5,5\% para 5,3\%) e divergência significativa para os documentos, de 4,3\% para 2,7\%, ou redução de $37 \%$.

Estas evidências sugerem que as articulações interregionais econômicas e da circulação em geral, características de Minas Gerais no século $\mathrm{XIX},{ }^{55}$ encontravam tradução diferenciada quanto à distribuição de recursos para obras públicas. A partir dos dados apresentados, pode-se afirmar a vigência de hierarquia das vias interregionais, com importância mais do que proporcional daquelas associadas a regiões com NDE alto, que capturavam quase todos os recursos públicos destinados a esse tipo de intervenção.

As regiões com NDE alto respondiam por 22,9\% da extensão territorial da província, 59,7\% da população em 1870 e 94,5\% da documentação referente a obras viárias interregionais. As regiões com NDE médio e baixo respondiam por $77,1 \%$ da extensão territorial da província, 40,3\% da população em 1870 e apenas 5,5\% da documentação relativa a obras viárias interregionais.

A concentração das obras viárias interregionais é ainda maior se considerado que a região MCLeste respondia sozinha por $80 \%$ dos Processos e documentos do agregado com NDE médio referentes a obras interregionais. Certamente em articulação com as regiões MCOeste e Diamantina, do agregado com NDE alto, com as quais mantinha históricas vinculações como zona de produção de alimentos para o mercado interno dos antigos núcleos mineradores. ${ }^{56}$

Conquanto sem nenhum processo, a região do Sertão do Rio Doce perfazia $60 \%$ dos documentos referentes a vias com dimensão interregional do agregado com NDE baixo. Documentação associada à articulação viária do projeto de colonização do Mucuri com o norte da província.

55 PAIVA, Clotilde Andrade. População e economia nas Minas Gerais do século XIX.

56 GODOY, Marcelo Magalhães. Intrépidos viajantes e a construção do espaço. 
Tabela 5

Distribuição regional dos processos e documentos referentes a obras viárias inter-regionais dos Processos de Construção de Estradas e Pontes, Minas Gerais, 1840-1889

\begin{tabular}{|c|c|c|c|c|c|}
\hline \multirow{2}{*}{ Regiões } & \multicolumn{2}{|c|}{ Processos } & \multicolumn{2}{|c|}{ Documentos } & \multirow{2}{*}{$\begin{array}{c}\text { Média de } \\
\text { Documentos } \\
\text { por Processo }\end{array}$} \\
\hline & $\mathrm{N}^{0}$ & $\%$ & $\mathrm{~N}^{0}$ & $\%$ & \\
\hline Nível Alto de Desenvolvimento Econômico & 147 & 86,0 & 2.781 & 94,5 & 18,9 \\
\hline Diamantina & 12 & 7,0 & 96 & 3,3 & 8,0 \\
\hline Intermediária de Pitangui-Tamanduá & 11 & 6,4 & 289 & 9,8 & 26,3 \\
\hline Mineradora Central Oeste & 43 & 25,1 & 617 & 21,0 & 14,3 \\
\hline Mata & 26 & 15,2 & 700 & 23,8 & 26,9 \\
\hline Sudeste & 47 & 27,5 & 1,045 & 35,5 & 22,2 \\
\hline Sul Central & 8 & 4,7 & 34 & 1,2 & 4,3 \\
\hline Nível Médio de Desenvolvimento Econômico & 15 & 8,8 & 83 & 2,8 & 5,5 \\
\hline Vale do Alto-Médio Rio São Francisco & -- & -- & -- & -- & -- \\
\hline Triângulo & -- & -- & -- & -- & -- \\
\hline Araxá & -- & -- & -- & -- & -- \\
\hline Vale do Médio-Baixo Rio das Velhas & 2 & 1,2 & 17 & 0,6 & 8,5 \\
\hline Mineradora Central Leste & 12 & 7,0 & 64 & 2,2 & 5,3 \\
\hline Sudoeste & 1 & 0,6 & 2 & 0,1 & 2,0 \\
\hline Nível Baixo de Desenvolvimento Econômico & 9 & 5,3 & 78 & 2,7 & 8,7 \\
\hline Sertão & 5 & 2,9 & 19 & 0,6 & 3,8 \\
\hline Minas Novas & 4 & 2,3 & 13 & 0,4 & 3,2 \\
\hline Paracatu & -- & --- & -- & --- & --- \\
\hline Sertão do Alto Rio São Francisco & -- & --- & -- & --- & --- \\
\hline Sertão do Rio Doce & -- & --- & 46 & 1,6 & --- \\
\hline Minas Gerais & 171 & 100 & 2.942 & 100 & 17,2 \\
\hline
\end{tabular}

Fontes: APM, SPOP 3/6: Seção Provincial, Obras Públicas, Processos de Construção de Estradas e Pontes, caixas 2 a 12 e 32 a 39.

Em síntese, a grande concentração observada deve ser associada ao dinamismo econômico que suportava as ligações interregionais a partir 
da base territorial das regiões do agregado com NDE alto. Notadamente quando se projetavam em articulações interprovinciais com o Rio de Janeiro. Em sentido inverso, demonstram que o poder público atuava de forma discriminatória com relação à dinâmica interna do comércio e circulação em geral, já que privilegiava determinadas articulações e excluía outras. Os resultados não autorizam tomar a baixa incidência ou ausência de Processos e documentos como indicador da inexistência ou inexpressividade de articulações interregionais a partir ou entre regiões com NDE médio e baixo, ${ }^{57}$ uma vez que essas articulações foram demonstradas pela historiografia, especialmente por Clotilde Paiva ${ }^{58}$ (Paiva e Godoy, 2001).

Internamente ao agregado com NDE alto, é destacável a concentração em 3 regiões das obras em vias de articulação interregional. São elas MCOeste, Mata e Sudeste, que respondiam por quase $80 \%$ dos Processos e $85 \%$ dos documentos do agregado com NDE alto. As razões para tamanha concentração estão relacionadas com a posição geográfica, base econômica e importância político-administrativa dessas regiões, como referido anteriormente.

As médias de documentos por Processos em intervenções em vias com articulação interregional reafirmam a assimetria da distribuição de recursos. O número médio de documentos por processo para o agregado de regiões com NDE alto era mais de 3 vezes superior ao agregado com NDE médio $(18,9$ para 5,5) e 2 vezes maior que o com NDE baixo $(18,9$ para 8,7) (Tabela 5).

\section{À guisa de conclusão: Transportes tradicionais e o crescimento da economia mineira}

Na época colonial as estradas tiveram um inimigo implacavel no governo portu-
guez, que prohibia a sua abertura para evitar o extravio do ouro e dos diamantes.
Proclamada a Independencia, apenas uma bôa estrada de rodagem União e
Industria, com 45 kilometros dentro de nossas fronteiras, se poude rasgar em
Minas durante a Monarchia, em razão das difficuldades do traçado em solo tão
accidentado e da escassez de recursos para financiar obras de vulto.Em 1869
inaugurou-se o primeiro trecho ferro-viario ligando um pedaço de Minas, na
fronteira, com o porto do Rio de Janeiro. As cargas que dalli vinha ou para alli
iam, eram conduzidas do immenso interior ate a ponta dos trilhos da ferro-via
exclusivamente em lombo de burro e em pesados carros de bois que, em via-
gens, vagarosissimas, se eternizavam por caminhos emmaranhados e difficeis

57 É necessário considerar que o panorama das obras provinciais que pode ser elaborado a partir dos Processos é parcial, já que diz respeito somente às obras que tiveram algum tipo de participação da administração provincial. Em Minas Gerais, no período analisado, o Governo Provincial não era o único a construir e conservar as estradas e pontes; as câmaras e os particulares, concomitantemente à administração provincial, também se ocupavam dessa tarefa; BARBOSA, Lidiany Silva. Tropas e ferrovias em uma província não-exportadora, p.111-127.

58 PAIVA, Clotilde Andrade; GODOY, Marcelo Magalhães. Território de contrastes. 
abertos ao acaso nas escarpas das montanhas e nos valles dos rios. Esses meios de transporte, pela sua morosidade pela sua careza e pela sua limitada capacidade, impediam o desenvolvimento do commercio. ${ }^{59}$

A compreensão da realidade dos transportes de Minas Gerais que se propõe a partir das evidências encontradas nos Processos é diametralmente oposta à, exemplarmente, oferecida pela citação que abre esta seção. Extraída do estudo "bem documentado" de Afrânio de Carvalho, segundo avaliação de Teixeira de Freitas, então diretor do Serviço de Estatística de Minas Gerais, o excerto em destaque traz os elementos fundamentais que se buscou combater neste texto: i. o caráter espontâneo e caótico da construção das vias no século XIX; ii. os meios e vias de transportes (tropas de mula e estradas de terra) como barreiras per si ao desenvolvimento econômico; iii. a ausência de iniciativas públicas no setor de transportes no período em tela; iv. as ferrovias inaugurando a fase "moderna" da história dos transportes em Minas Gerais.

Da leitura da íntegra do referido trabalho de Afrânio de Carvalho não é difícil depreender que sua avaliação baseia-se em compreensão da economia mineira no século XIX, esgotado o "ciclo do ouro", enquanto economia ruralizada e decadente. Entretanto, se no trecho aqui destacado tais elementos estão sintetizados, embora de forma integrada, e se baseiam em compreensão específica da economia mineira oitocentista, é essencial ressaltar que, quando o assunto são os transportes de Minas Gerais no período pré-ferroviário, tais noções são amplamente difundidas e reiteradas na historiografia, independente da compreensão da economia mineira que Ihes subjaz. Assim sendo, não será difícil demonstrar que a profunda revisão historiográfica sobre a economia de Minas Gerais no século XIX, em curso desde o início da década de 1980, não foi acompanhada de revisão correspondente no específico sobre os transportes. Os dados recolhidos nos Processos permitem divisar realidade dos transportes em Minas Gerais muito mais ampla e complexa do que o dominante interesse pelos caminhos coloniais, em especial as estradas reais, e pelas ferrovias.

Sabe-se que para os contemporâneos a infra-estrutura aqui apresentada, assim como os meios que lhes correspondiam, não fizeram jus, como as estradas de ferro e suas máquinas a vapor, a epítetos maravilhosos. As estradas de terra, as pontes de madeira e pedra, assim como as morosas tropas de mulas, não ofereciam espetáculos, ruídos assustadores, sibilos, vapores promotores de movimentos vertiginosos, entre outras impressões fortes. Essas vias tradicionais, aliás, receberam reiteradas vezes alcunhas de péssimas, de em ruínas, análogas a pântanos, a projetar os viajantes em

59 CARVALHO, Afrânio de. A actualidade mineira. Belo Horizonte: Imprensa Oficial e Secretaria de Agricultura - Serviço de Estatística, 1929, p.91-92. 
abismos tenebrosos, entre outras adjetivações e qualificações negativas. ${ }^{60}$ Ainda que seja objeto relevante ao historiador a consideração de certos aspectos culturais fortemente associados ao processo de modernização dos transportes, impõe-se, contudo, a tarefa de compreender o conjunto de determinações que presidiram cada experiência concreta. No caso de Minas Gerais, os Processos evidenciam o peso da infra-estrutura de transportes tradicionais e a vigência de relação estreita entre fatores políticos e econômicos na alocação de vultosos recursos públicos que asseguraram a conservação e ampliação da muito provavelmente maior malha viária provincial do país. ${ }^{61}$

A estrutura viária anterior à era ferroviária mineira sustentou de forma funcional, mesmo que deficitariamente, economia dinâmica e em expansão. ${ }^{62}$ A extensa e intricada malha de estradas e caminhos, quase exclusivamente sem pavimentação, e pontes, majoritariamente de madeira, mantida e expandida ao longo de todo o período analisado, era fruto do contextual. Contextual aqui entendido no sentido amplo da palavra que, necessariamente, deve contemplar reflexões sobre o caráter técnico desta infra-estrutura. No particular da qualidade das estradas e pontes do Dezenove, sobretudo o historiador não deve olvidar "que a técnica é tanto este possível que os homens por razão, sobretudo econômicas e sociais, psicológicas também, são capazes de atingir e de utilizar plenamente, como também é este teto em que batem materialmente, 'tecnicamente', os seus esforços". ${ }^{63}$ No específico deste trabalho, evidencia-se o empenho contínuo do Governo Provincial, nos limites dos recursos materiais e técnicos disponíveis, e segundo uma série de injunções econômicas, políticas e sociais, em prover a necessária infra-estrutura viária ao crescimento da mais populosa e entre as mais dinâmicas economias do Brasil imperial.

60 Os Inquéritos Provinciais, que estão sob a guarda do Arquivo Público Mineiro, conformam extenso conjunto documental referente ao século XIX em que se pode recolher evidências exuberantes dessas adjetivações e qualificações por parte dos coevos. Sobre as características dos Inquéritos ver BARBOSA, Lidiany Silva. Os inquéritos provinciais das décadas de 1850 e 1860 e a percepção e propostas de intervenção na infra-estrutura de transportes de Minas Gerais. Anais Primer Congreso Latinoamericano de Historia Económica y Cuartas Jornadas Uruguayas de Historia Econômica, 2007.

61 A rubrica obras públicas, em que predominava largamente o dispêndio com obras viárias, ocupou lugar de destaque nas finanças públicas de Minas Gerais durante todo o período provincial. BARBOSA, Lidiany Silva; GODOY, Marcelo Magalhães; MENDES, Philipe Scherrer. Transportes e finanças públicas.

62 GODOY, Marcelo Magalhães; BARBOSA, Lidiany Silva. Uma outra modernização: transportes em uma província não exportadora, Minas Gerais, 1840-1889. Revista Economia e Sociedade, São Paulo, v.17, p.159-186, 2008.

63 BRAUDEL, Fernand. Civilização material, economia e capitalismo. Séculos XV-XVIII: as estruturas do cotidiano. v.1, São Paulo: Editora Martins Fontes, 1995, p.305. 


\section{Anexo}
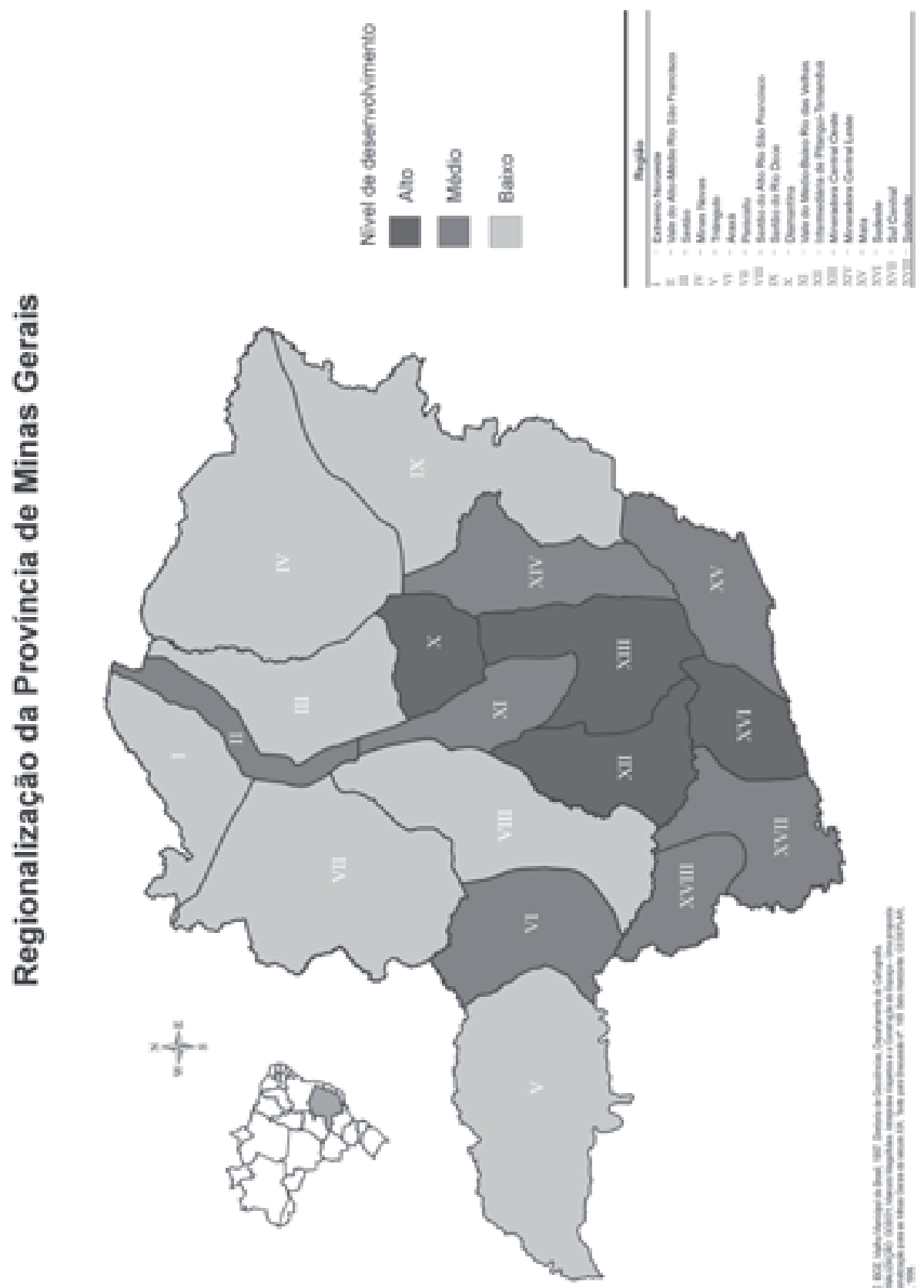

Nota: A classificação das regiões segundo o Nível de Desenvolvimento Econômico (NDE) foi redefinida para a segunda metade do século XIX. Baseado em dados demográficos e econômicos, o Triângulo passou para o NDE Médio, Sul Central e Mata para o NDE Alto. 